\title{
ACTINIC LESIONS IN FISHERMEN'S LOWER LIP: CLINICAL, CYTOPATHOLOGICAL AND HISTOPATHOLOGIC ANALYSIS
}

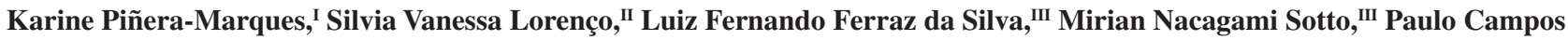 \\ Carneiro ${ }^{\text {III }}$
}

doi: $10.1590 / \mathrm{S} 1807-59322010000400003$

Piñera-Marques K, Lorenço SV, Silva LFF, Sotto MN, Carneiro PC. Actinic lesions in fishermen's lower lip: clinical, cytopathological and histopathologic analysis. Clinics. 2010;65(4):363-7.

INTRODUCTION: Actinic cheilitis (AC) is considered to be a pre-malignant lesion or an incipient and superficial form of lip squamous cell carcinoma. It is commonly found in individuals whose occupational activities are related to chronic sun exposure and the definitive diagnosis is performed with biopsy. Althoug Exfoliative cytology has been used as a screening procedure to evaluate cancer of the oral cavity no studies have proposed the use of exfoliative cytologic analysis to evaluate and diagnose AC. OBJECTIVE: The purpose of this study was to evaluate lower lip lesions on fishermen related to chronic solar exposure using clinical, cytologic and histopathologic analyses.

PATIENTS AND METHODS: Smears taken from the vermilion of the lower lips of 125 fishermen and 30 control individuals were subjected to cytologic analysis.

RESULTS: The harvested cells were sufficient for cytologic analysis in $83.2 \%$ of the samples. Sixteen fishermen exhibited prominent lower lip lesions that justified biopsy and histological studies. In total, 4 specimens were malignant (3.2\%), and 12 displayed epithelial dysplasia, demonstrating that the prevalence of epithelial dysplasia and malignant lesions was high among the fishermen population. These conditions were strongly associated with infiltration and blurring of the vermilion margin of the lower lip.

CONCLUSION: The cytologic analysis was not useful for detecting epithelial dysplasia or malignant alterations.

KEYWORDS: Actinic cheilitis ; Lip carcinoma ; Pre-malignant lesion ; Exfoliative cytology.

\section{INTRODUCTION}

Actinic cheilitis is considered to be a pre-malignant lesion or an incipient and superficial form of lip squamous cell carcinoma (SCC). It is commonly found in individuals whose occupational activities are related to chronic sun exposure, especially fishermen. ${ }^{1-7}$ The clinical changes of actinic cheilitis include erythema, keratosis, atrophy, erosion, crusts and fissures. Infiltration and blurring of the

\footnotetext{
I General Pathology Department, Universidade do Sul de Santa Catarina (Unisul) - Palhoça/ SC, Brazil.

II General Pathology Department - University of São Paulo Dental School - São Paulo/SP, Brazil.

III Department of Pathology, Faculdade de Medicina da Universidade de São Paulo - São Paulo/SP, Brazil.

Tel.: +55 483221.7569

Email: karine.pinera@unisul.br

Received for publication on January 07, 2010

First review completed on January 15, 2010

Accepted for publication on January 15, 2010
}

vermilion margin are clinical signs that correlate with lower lip neoplasia. ${ }^{8-10}$

No consensus has been reached in the literature regarding the clinical manifestations and histopathologic aggressiveness of actinic cheilitis (AC), thus histopathologic analyses should be used to confirm this condition. ${ }^{9,10}$ Exfoliative cytology has been used as a screening procedure to evaluate oral premalignant lesions and cancer of the oral cavity. ${ }^{11-14}$

Considering the well-established association between AC and lower-lip SCC, especially in patients at risk, we herein suggest procedures to increase the diagnostic accuracy for this lesion. Exfoliative cytology is a non-invasive and low-cost examination technique that may be useful for the assessment of lower lip AC and SCC, as it has been used to screen and diagnose pre-malignant oral lesions. ${ }^{15-29}$ However, few studies have used exfoliative cytology for oral lip lesions. To our knowledge, no studies have proposed the use of exfoliative cytologic analysis to evaluate and diagnose AC. 
The aim of this study was to evaluate the clinical, cytologic and histopathologic features of AC in fishermen living in the city of Florianopolis, in the state of Santa Catarina, Brazil.

\section{MATERIALS AND METHODS}

The studied sample included 125 fishermen with a history of chronic sun exposure (FG) living in Florianopolis, Santa Catarina, Brazil (latitude $27^{0} 35^{\prime} 48^{\prime}$ ' S, longitude $48^{\circ}$ 32' 57' O). The control group $(n=30)$ did not have a history of chronic sun exposure (CG) and included individuals selected from the same geographic region who generally participated in only indoor activities. The study was approved by the Research Ethics Board of the institution. Informed consent was obtained from all patients.

Clinical manifestations including erythema, desquamation, fissure, infiltration, atrophy, ulceration, crust, leukokeratosis and blurring of the vermilion margin were graded according to their severity from 0 (absent) to 4 (intense). ${ }^{9,10}$

The patients in control group (CG) were evaluated for clinical features that could indicate lip epithelial dysplasia or malignancy.

All individuals underwent lower-lip exfoliative cytology with a metal spatula. ${ }^{32,33,11}$ The parched lip areas were humidified with saline solution for 10 minutes and scraped to remove the excess keratin. ${ }^{30,31}$ Cytologic smears were fixed in a $70 \%$ alcohol solution ${ }^{33,14}$ and stained by Papanicolaou's method.

The cytologic analysis evaluated the following: 1) cellular characteristics, as defined for gynecological smears (Bibbo, 1997; Koss, 1992); 2) oral smear pattern, as proposed by Silva (1997); and 3) the correlation between cytologic characteristics and histopathologic findings in biopsied patients. The number of cells in the smears was scored from absent / inconclusive (0) to intense (3).

Patients that presented blurring of the vermilion margin, infiltration of the lower lip $^{9}$ and cytologic results suggestive of dysplasia/malignancy underwent a biopsy and histopathologic analysis.

The specimens were obtained using punch or scalpel biopsy. The specimens were fixed in $10 \%$ formalin and stained with hematoxylin and eosin. The histopathologic analysis used the cytologic and architectural criteria proposed by the WHO (1978), Pindborg et al. (1997) and Nico et al. (2007). Three independent, blinded pathologists performed the cytologic and histopathologic analyses.

The data obtained were compared using the Chi-square, Mann-Whitney and Kruskall-Wallis tests in SPSS version 15.0 (spssinc $\subset$ ) $)$ p $<0.05$ was considered significant.

\section{RESULTS}

The control group consisted of 28 male and 2 female Caucasians, with a mean age of $50.6 \pm 6.4$ years. The fishermen group (FG) included 125 Caucasians (121 males and 4 females) with a mean age of $50.58 \pm 12.77$ years. The sunlight exposure period for the FG was 32.14 \pm 12.47 years, with an average of $7.71 \pm 1.23$ hours/day. In total, $92.8 \%$ of the fishermen did not use any type of sunscreen protection. Alcohol consumption was observed in $32 \%$ and smoking in $38.4 \%$ of the fishermen. Only $2 \%$ of fishermen were aware of the malignant potential of their lip lesions.

The characteristic clinical manifestations of the actinicinduced alterations were mild in this sample (Table 1). Lower lip biopsies were obtained from 16 fishermen (12.8\%) based on the abovementioned clinical criteria.

Table 1 - Lower lip clinical alterations in the fishermen group.

\begin{tabular}{lcc}
\hline Clinical Alteration & Mean & SD \\
\hline Erythema & 0.32 & 0.78 \\
Desquamation & 0.22 & 0.62 \\
Fissure & 0.10 & 0.49 \\
Infiltration & 0.19 & 0.56 \\
Atrophy & 0.33 & 0.67 \\
Ulceration & 0.11 & 0.41 \\
Leukokeratosis & 0.11 & 0.32 \\
Blurring of vermilion margin & 0.22 & 0.64 \\
Variegated red / white lip aspect & 0.61 & 1.00 \\
\hline
\end{tabular}

Mean score 0-4: 0, absent; 1, small / discrete; 2, mild; 3, high / intense; 4, very high / very intense

The number of cells in the FG smears was lower than that in the $\mathrm{CG}$, and the number of inconclusive cases (cellular amount $=0)$ was significantly higher in the FG $(\mathrm{p}<0.001)$. Although the cellular amount in the FG smears was lower, the exfoliative cytology displayed more intermediate $(\mathrm{p}<0.001)$ and atypical (inflammatory) squamous cells $(\mathrm{p}=0.027)$ in the FG than in the CG (Table 2).

\section{Histopathologic Findings}

Histopathologic analysis identified four SCCs (two in situ carcinoma and two superficially invasive SCCs), seven cases of light dysplasia and five cases of mild dysplasia. No correlation was observed between dysplasia or malignancy and age or sunlight exposure time. Table 3 presents the mean scores for each morphological feature observed in the 16 lower-lip biopsies. 
Table 2 - Comparison of cell number in the smears in the control and fishermen groups.

\begin{tabular}{lllccccc}
\hline & & & \multicolumn{3}{c}{ Score for number of cells } & \multicolumn{2}{c}{ Total } \\
\cline { 3 - 6 } & & & $\mathbf{0}$ & $\mathbf{1}$ & $\mathbf{2}$ & $\mathbf{3}$ & $3(100 \%)$ \\
\hline \multirow{2}{*}{ Group } & Control & $\mathbf{N}$ & $0(0 \%)$ & $0(0 \%)$ & $7(23.3 \%)$ & $23(76.7 \%)$ & $30(25)$ \\
& Fishermen & $\mathbf{N}$ & $7(5.6 \%)$ & $14(11.2 \%)$ & $79(63.2 \%)$ & $25(20.0 \%)$ & $125(100 \%)$ \\
\hline
\end{tabular}

$\mathrm{p}<0.001 ; \mathrm{X}^{2}$ test

Table 3 - Mean scores of the histopathologic features observed in 16 lower-lip biopsies.

\begin{tabular}{lcc}
\hline Histopathologic feature & Mean & SD \\
\hline Droplet form of epithelial crests & 0.69 & 0.60 \\
Basal layer duplication & 1.25 & 0.77 \\
Hypercellularity & 1.31 & 0.87 \\
Epithelial maturation alteration & 1.13 & 0.89 \\
Ulceration & 0.06 & 0.25 \\
Hyperkeratosis & 2.06 & 0.68 \\
Acanthosis & 2.00 & 0.82 \\
Atrophy & 0.00 & 0.00 \\
Prominent nucleolus & 1.13 & 0.72 \\
Nuclear hyperchromatism & 1.13 & 0.72 \\
Nuclear pleomorphism & 1.13 & 0.81 \\
Nucleus/cytoplasm ratio & 0.94 & 0.77 \\
Increase of mitotic figures & 0.25 & 0.45 \\
Atypical mitosis & 0.00 & 0.00 \\
Nucleated cells & 0.00 & 0.00 \\
Lichenoid inflammatory infiltrate & 0.44 & 0.89 \\
Diffuse inflammatory infiltrate & 0.44 & 0.63 \\
Focal inflammatory infiltrate & 0.19 & 0.54 \\
Elastosis & 1.94 & 1.24 \\
Fibrosis & 0.00 & 0.00 \\
\hline
\end{tabular}

\section{DISCUSSION}

The epidemiological profile of the FG concerning smoking and chronic sunlight exposure supports the data in the literature regarding $\mathrm{AC}$. The results obtained in this study were also similar to the first description of $\mathrm{AC}$ and other published data. ${ }^{8,34,35}$

In this study, there was no correlation between age or sunlight exposure time and the histopathologic diagnosis of dysplasia or malignancy. This may reflect the difficulty in predicting the malignant transformation of pre-malignant lesions, even with well-defined etiological factors. ${ }^{36}$

All biopsied fishermen presented dysplastic or malignant alterations, showing that the established criteria for indication of biopsy ${ }^{9}$ had $100 \%$ specificity for dysplasia/ malignancy. The presence of pre-malignant lesions has been associated with malignant transformation. ${ }^{41,42}$

In our study, 12 cases showed assorted dysplasia grades at the histopathologic examination. Four $(3.2 \%)$ of the fishermen presented the histopathologic diagnosis of SCC. This prevalence is slightly higher than that reported for the normal population. ${ }^{33}$ Lip cancer incidence in Brazil is $2.2 / 100,000$ cases per year. In the southern region of Brazil, the incidence is $1.2 / 10,000$ cases. $^{33}$

Considering the discrepancy between the clinical alterations of AC and the histopathologic findings, particularly when evaluated in a single biopsy, the use of other techniques with improved diagnostic accuracy as well as methods (such as cytologic smears) that could be used as screening tools is very important. In this study, we evaluated exfoliative cytology as an effective option for the early diagnosis of $\mathrm{AC}$, and used smears as a screening tool to determine the best area for biopsy.

Dysplastic alterations occur in the deeper epithelial layers. For this reason, the cytologic diagnosis of keratinized lesions can be difficult. Studies evaluating the quality, sensitivity and specificity of cytologic examinations for oral cancer and pre-malignant lesions usually refer to intra-oral lesions. There are no published cytologic results for lip lesions associated with AC and lower-lip cancer.

The sample quality, according to the number of cells obtained from the lower-lip smears of the fishermen, was considered adequate for evaluation (scores 2 and 3 ) in $83.2 \%$ of cases. The few cytologic studies that have addressed lip lesions discussed the difficulty of cell harvesting, due to lip dryness and keratinization. In our study, this difficulty was overcome by first humidifying the lip with saline solution and then using a metal spatula to attain more intense frictional contact with the selected area. ${ }^{11-14}$

Although recent studies have supported the use of exfoliative cytology for oral pre-malignant and malignant diagnoses, our study clearly shows that such analyses should not be used for strictly morphological diagnosis of AC and lower-lip cancer. ${ }^{11,13,23}$

Pathological studies of AC and SCC have shown that these lesions can develop from the basal epithelial layer to the lamina propria, or even present alterations throughout all epithelial layers before evolving into fully developed malignant lesions. ${ }^{34}$ 
The sensitivity and specificity of exfoliative cytology may be enhanced when associated with novel technologies such as tumor markers, p53 identification, cytomorphometry, growth factors, gene expression and others. ${ }^{11-13,15-17,19-24}$ It is known that AC and SCC present molecular alterations even before their morphological features develop. It is possible that these alterations may be demonstrated in adequate cellular samples (even superficial and intermediate ones). Exfoliative cytology might be a non-invasive tool for initial studies of AC and lip cancer when used with the aforementioned new techniques.

Considering the data obtained, we conclude that the studied fishermen presented a high prevalence of actinically induced lesions. These conditions were strongly associated with infiltration and blurring of the vermilion margin of the lower lip. Routine exfoliative cytology was not useful for screening pre-malignant and malignant lower-lip lesions.

\section{REFERENCES}

1. Hurwitz RM, Monger LE. Solar radiation: an envolving squamous cell carcinoma: benign or malignant? Dermatol Surg. 1995;21:184.

2. Visscher JGAM, Van Der Waal I. Etiology of cancer of the lip. Int J Oral Maxillofac Surg. 1998;27:199-203.

3. Heaphy M, Ackerman AB. The nature of solar keratosis: a critical review in historical perspective. J Am Acad Dermatol. 2000;43:138-50.

4. Moy RL. Clinical presentation of actinic keratosis and squamous cell carcinoma. J Am Acad Dermatol. 2000;42:S8-10.

5. Ackerman AB. Actinic cheilitis? In: Resolving quandaries in dermatology, pathology and dermatopathology. New York: Ardor Scribendi; 2001a. v.2, p.20.

6. Ackerman AB. Actinic cheilitis? In: resolving quandaries in dermatology, pathology and dermatopathology., New York: Ardor Scribendi; 2001 b. v.2, p.3-6.

7. Ackerman AB. Opposing views of two academies about the nature of solar keratosis. Cutis. 2003;71:391-5.

8. Ayres S. Chronic actinic cheilitis. JAMA. 1923;81:1183-6.

9. Aguiar SM. Contribuição ao estudo da queilite actínica: correlação anátomo-clínica [tese]. São Paulo: Faculdade de Medicina, Universidade de São Paulo; 1995

10. Nico MMS, Rivitti EA, Lourenço V. Actinic cheilitis: histologic study of the entire vermilion and comparison with previous biopsy. J Cutan Pathol. 2007:34:309-14.

11. Jones AC, Pink FE, Sandow PL, Stewart CM, Migliorati CA, Baughman RA. The cytobrush plus cell collector in oral cytology. Oral Surg Oral Med Oral Pathol Oral Radiol Endod. 1994;77:101-4.

12. Ogden GR, Leigh I, Chisholm DM, Cowpe JG, Lane EB. Exfoliative cytology of normal oral mucosa. Assessing the basal cell keratin phenotype. Acta Cytol. 1996;40:933-6.

13. Ogden GR, Cowpe JG, Wight AJ. Oral exfoliative cytology: review of methods of assessment. J Oral Pathol Med. 1997;26:201-5.

14. Roberts DM. Comparative cytology of the oral cavities of snuff users. Acta Cytol. 1997;41:1008-14.

15. Macluskey M, Ogden GR. An overview of the prevention of oral cancer and diagnostic markers of malignant change: 2 . Markers of value in tumour diagnosis. Dent Update. 2000;27:148-52.
16. Giese M, Friedrich RE, Riethdorf S, Löning T. Detection of p53 mutation in patients with oral squamous epithelial carcinoma. Mund Kiefer Gesichtschir. 2001;5:37-43.

17. Caruntu ID, Scutariu MM, Dobrescu G. Computerized morphometric discrimination between normal and tumoral cells in oral smears. J Cell Mol Med. 2005;9:160-8.

18. Epstein JB, Zhang L, Rosin M. Advances in the diagnosis of oral premalignant and malignant lesions. J Can Dent Assoc. 2002;68:617-21.

19. Diniz-Freitas M, García-García A, Crespo-Abelleira A, Martins-Carneiro JL, Gándara-Rey JM. Aplicaciones de la citología exfoliativa en el diagnóstico del cáncer oral. Med Oral. 2004;9:355-61.

20. Acha A, Ruega MT, Rodríguez MJ, Pancorbo MAM, Aguirre JM. Aplicaciones de la citología oral por raspado (exfoliativa) em el cáncer y precáncer oral. Med Oral Patol Oral Cir. 2005;10:95-102.

21. Brunotto M, Zárate AM, Cismondi A, Fernández MC, Halac RIN. Valoración de la citología exfoliativa como factor de predicción en lesiones de la mucosa oral. Med Oral Patol Oral Cir Bucal. 2005;10(Suppl 2):E92-102.

22. Mehrotra R, Gupta A, Singh M, Ibrahim R. Application of cytology and molecular biology in diagnosing premalignant or malignant oral lesions. Mol Cancer. 2006;23:5:11.

23. Schwartz JL, Panda S, Beam C, Bach LE, Adami GR. RNA. from brush oral cytology to measure squamous cell carcinoma gene expression. J Oral Pathol Med. 2008;37:70-7.

24. Staats OJBA, Goldsby JW. Graphic comparison of intraoral exfoliative cytology technics. Acta Cytol. 1963;7:107-12.

25. Silva MCA. Citopatologia: um recurso auxiliar na prevenção do câncer oral em pacientes do sexo masculino [dissertação]. Porto Alegre: Faculdade de Odontologia, Universidade Federal do Rio Grande do Sul; 1997.

26. Vidal AKL, Silva JF. Correlação cito-histopatológica e aplicabilidade do corante azul de toluidina a $2 \%$ em lesões de mucosa oral. Rev Conselho Regional de Odontologia de Pernambuco. 1999;2:59-72.

27. Bibbo M. Comprehensive cytopathology. $2^{\text {nd }}$ ed. Philadelphia: W B Saunders Company; 1997.

28. Kramer IR, Lucas RB, Pindborg JJ, Sobin LH. Definition of leukoplakia and related lesions: an aid to studies on oral precancer. Oral Surg Oral Med Oral Pathol. 1978;46:518-39. 
29. Pindborg JJ, Reichart PA, Smith CJ, van der Wall I. Organização Mundial da Saúde (OMS). International histological classification of tumors. Histological typing of cancer and precancer of the oral mucosa. $2^{\text {nd }} e d$. Berlin: Springer; 1997.

30. Markopolous A, Albanidou-Farmaki E, Kayavis I. Actinic cheilitis: clinical and pathologic characteristics in 65 cases. Oral Dis. 2004;10:212-6.

31. Napier SS, Speight P M. Natural history of potencially malignant oral lesions and conditions: an overview of the literature. J Oral Pathol Méd. 2008;37:1-10.
32. Awde JD, Kogon SL, Morin RJ. Lip cancer: a review. J Can Dent Assoc. 1996;62:634-6.

33. Moore SR, Johnson NW, Pierce AM, Wilson DF. The epidemiology of lip cancer: a review of global incidence and aetiology. Oral Dis. 1999;5:185-95.

34. Wening BM. Squamous cell carcinoma of the upper aerodigestive tract: precursors and problematic variants. Mod Pathol. 2002;15:229-54. 